\title{
Impacts of Different Land Use on Some Selected Soil Physicochemical Properties in Federal Polytechnic Idah, Kogi State, Nigeria
}

\author{
Paul Omaye Joseph*, Ojomah Frank Ojochegbe, Amhakhian Sunday Okonfor, Ukaha Chinwe Faith \\ Department of Soil and Environmental Management, Faculty of Agriculture, Kogi State University, Anyigba, Nigeria

\section{${ }^{*}$ Corresponding Author} \\ Paul Omaye Joseph
}

\author{
Article History \\ Received: 13.07.2019 \\ Accepted: 22.07 .2019 \\ Published: 30.07 .2019
}

\begin{abstract}
The continuous use of land for agricultural production could lead to land degradation, nutrients depletion, declined crop production and environmental degeneration. This study was therefore conducted to investigate the impacts of land use on physicochemical properties of soils of oil palm plantation, cultivated land and fallow land. Twenty-one (21) soil samples were collected from each land use type at a depth of $0-20 \mathrm{~cm}$, giving a total of sixty-three (63) samples, and bulk together to make three composite samples; one for each land use type, and analyzed for selected physical and chemical properties using standard methods. The results of the study, on one hand, revealed that organic matter, total nitrogen, available phosphorus, exchangeable calcium, magnesium, potassium, CEC, PBS, organic carbon, exchangeable acidity and $\mathrm{pH}$ contents of the cultivated land were significantly $(\mathrm{P}<0.05)$ lower than the adjacent fallow land. On the other hand, the result revealed that exchangeable calcium, magnesium, potassium, CEC, PBS and exchangeable acidity contents of the oil palm plantation were significantly $(\mathrm{P}<0.05)$ lower than the adjacent fallow land. However, there was no significant difference between the fallow land and oil palm plantation in available phosphorus, exchangeable sodium, organic carbon, total nitrogen and organic matter. Available phosphorus and ECEC were high for all the land use types. The $\mathrm{pH}$ in all the land use types was moderately acidic. From the present study, it could be concluded that the soil quality and health were maintained relatively under the fallow land, whereas the influence on most parameters were negative on the soils of the cultivated land. The continuous cultivation of the land has degraded the soil properties and there is therefore the need to adopt appropriate management practices to achieve high soil quality and sustainable productivity.
\end{abstract}

Keywords: Cultivated land, fallow land, land use type, oil palm plantation, physicochemical

\section{INTRODUCTION}

There is an increasing need to gather facts relating to soil conditions, their current status, changes due to land uses and management practices. Given the intense pressure on the ecosystem and the continuous decline especially in soil fertility due to demographic explosion, such information becomes necessary for appropriate soil planning and management [1].

Lands have been highly exploited for all purposes at the expense of their suitability, which have led to overwhelming land degradation [2, 3]. It has been reported that non-methodic changes in land use predispose it to various environmental problems amongst which include desertification, acidification, eutrophication, greenhouse effect that cause climate change and biodiversity loss $[4,5]$. FAO [6] observed that about $20 \%$ of the world's agricultural lands have been irreversibly damaged due to a rapid land degradation and intensive land use, leading to a decrease of about $15-30 \%$ of their productivity. In Nigeria, estimated annual land loss to degradation have been noted to range from $5-7$ million hectares in 1981 and to about 10 million hectares in 2000 [7].

Land degradation has serious effect on soil physical and chemical properties especially infiltration, bulk density, organic matter, porosity and aggregate stability causing compaction and erosion [8]. This has an attendant implication on food production, health hazards and the ecosystem.

The available limited studies in Federal Polytechnic Idah, Kogi state indicated contrasting finding regarding the reaction of soil to land-use system. Efforts to address these problems are highly apt in order to actualize the agricultural transformation agenda of

Copyright @ 2019: This is an open-access article distributed under the terms of the Creative Commons Attribution license which permits unrestricted use, distribution, and reproduction in any medium for non commercial use (NonCommercial, or CC-BY-NC) provided the original author and source are credited. 
the Federal Government and meet the millennium development goals. Adequate study of soils of the various land use types will help generate information necessary for proper land use planning. Polytechnic Idah.

The aim of this study was to investigate the effect of different land use on soil physico-chemical properties in Federal

\section{MATERIALS AND METHODS Study area}

The study site, Idah, is located on the North-East part of Kogi State which lies between latitude $7^{0} 25^{\prime} \mathrm{N} / 7^{0} 14^{\prime} \mathrm{E}$. The general climate is humid tropical, having distinct raining and dry seasons. Kogi State has a bimodal rainfall with the peak pattern occurring in July and September. The mean annual rainfall ranges from $1560 \mathrm{~mm}$ at Kabba in the West to $1808 \mathrm{~mm}$ at Idah in the East. The temperature shows some variation throughout the year. Average monthly temperature varies from $17{ }^{\circ} \mathrm{C}$ to $36.2^{\circ} \mathrm{C}$. Relative humidity is moderately high and varies from an average of $65-85 \%$ throughout the year [9].

\section{Collection of samples}

Disturbed and undisturbed soil samples were collected from the different land use namely oil palm plantation, cultivated land and fallow land. These samples were collected from twenty-one spots in each of the land use types with the aid of an auger and bulk together to form three composite samples; one for each land use type. The land use types were either next to one another or separated by no more than $1 \mathrm{~km}$, within the same geographic location and with similar slope and aspect. Soil samples were taken at the depth of $0-20 \mathrm{~cm}$ (topsoil) in each of the three selected areas. Soil samples were taken in plastic bags to the laboratory and air dried for analysis.

\section{Soil Sample Preparation and Laboratory Analysis}

The soil samples were air-dried and ground to pass through $2 \mathrm{~mm}$ sieve. For the determinations of total $\mathrm{N}$ and organic carbon (OC), a $0.5 \mathrm{~mm}$ sieve was used. Analyses of the soil physicochemical properties considered in the study area were carried out following standard laboratory procedures.

Particle size distribution was determined using the Bouyoucos hydrometer method as modified by Gee and Or [10]. Organic carbon was determined using Walkey-Black method [11]. Percentage organic matter was calculated by multiplying the values of organic carbon by a factor of 1.724 (Van Bemmelen factor). Total nitrogen was determined by Kjeldahl digestion method [12]. Available phosphorus was determined by Bray and Kurtz [13] extraction method. Soil pH was determined using the pH meter [14]. Effective Cation Exchange Capacity (ECEC) was determined using Carter [15] summation method, by summing the total exchangeable bases to exchangeable acidity [16]. Exchangeable acidity was determined by leaching the soil with $1 \mathrm{M} \mathrm{KCl}$ and titrating with $0.05 \mathrm{M} \mathrm{NaOH}$ [17]. Percentage base saturation (PBS) was calculated by dividing total exchangeable bases by ECEC and multiplying by 100 [18].

\section{Statistical Analysis}

One-way analysis of variance (ANOVA) procedure was used to compare the effects of different land use on physical and chemical properties of soil using SPSS version 17. Separation of means of the soil properties was performed using Duncan significance test $(p<0.05)$. Additionally, Pearson's correlation coefficient was used to evaluate the relations of various soil physicochemical characteristics.

\section{RESULTS AND DISCUSSION}

The physical and chemical properties of land use types of Federal Polytechnic Idah are presented in table 1. The particle size distribution showed that the textural classes were sandy loam. This means that land-use did not have effect on the texture, because texture is largely determined by parent material [19]. However, sand content of the soils varied significantly $(P<0.05)$ among the land use types. The soils in the studied area have high percentage of sand, with low silt and clay fraction. The percentage of silt, apart from being low, showed no particular trend among the various soils. The percentage clay slightly increased within the land use types.

Contrary to believe that management practices do not change the textural class of the soil, it plays indirect roles in doing so over a long period of time. Weathering and erosion can alter soil texture [13]. Under conditions of low vegetation cover, as in the grazing land case, clay fractions are likely to be lost through processes of selective erosion and migration down the soil profile which ultimately increase the proportion of sand and silt contents in surface layers. A negative correlation $(r=-0.99, P<0.01)$ was observed between sand and clay. 
Table-1: Mean values of particle size distribution (\%) as influenced by the different land uses

\begin{tabular}{|l|l|l|l|l|l|}
\hline \multirow{2}{*}{ Soil properties } & \multicolumn{3}{|c|}{ Land use types } & LSD (0.05) & CV (\%) \\
\cline { 2 - 4 } & Oil palm plantation & Cultivated land & Fallow land & & \\
\hline Sand & $84.88^{\mathrm{a}}$ & $76.88^{\mathrm{b}}$ & $78.88^{\mathrm{b}}$ & 5.98 & 5.2 \\
\hline Silt & 0.92 & 1.42 & 1.42 & $0.61 \mathrm{~ns}$ & 23.1 \\
\hline Clay & $14.2^{\mathrm{b}}$ & $21.7^{\mathrm{a}}$ & $19.7^{\mathrm{a}}$ & 5.36 & 21.0 \\
\hline Textural class & Sandy Loam & Sandy Loam & Sandy Loam & & \\
\hline
\end{tabular}

Means within column followed by the same letter are not statistically different from each other at $P<0.05$; LSD = least significant difference; ns = not significant; CV = coefficient of variation.

The $\mathrm{pH}$ in water of the soils ranged from $5.20-6.50$. The soils were moderately acidic; this could be due to the abundance of iron and aluminum ions, and the resultant net reduction in the soil $\mathrm{pH}[20]$. The $\mathrm{pH}$ of oil palm plantation is significantly different $(\mathrm{P}<$ 0.05 ) from cultivated land and fallow land; this could be ascribed to inorganic fertilizer application (in cultivated land and fallow land) and severe base leaching by the high tropical rainfall [21].

The available $P$ contents of the soils under all land uses ranged from $9.02-11.45 \mathrm{mg} / \mathrm{kg}$. Oil palm plantation and fallow land are not significantly different but are significantly different from cultivated land (Table 2); this could be due to crop mining, crop residue removal and erosion in cultivated land.

Percent base saturation ranged from $85.22-90.43 \%$. There was significant difference among all land use types, and it increased from cultivated land to oil palm plantation and to fallow land. The result of this study is in agreement with the findings of Bahilu et al. [22]. This could be as a result of relatively high organic matter on the surface of fallow land than oil palm plantation and cultivated land respectively.

Soil organic carbon ranged from $1.42-2.04 \%$. Oil palm plantation and fallow land are not significantly different but are significantly different from cultivated land; this could be due to the higher litter accumulation in oil palm plantation and fallow land. Low organic carbon content of the cultivated land could be due to rapid decomposition and depletion of plant materials. Reduction in soil organic carbon due to conversion of forests into more intensive land uses have been reported [7, 23, 24, 21, 25]. Values of soil organic carbon of the various land uses are low compared to the critical levels of $15-20 \mathrm{gkg}^{-1}(1.5-2.0 \%)$ for tropical soils [26] and 25.0, 30.0 and $35.0 \mathrm{gkg}^{-1}$ for soils of Western, Northern and Eastern Nigeria respectively [27]. The general low levels could be as a result of management practices involving high burning and intensive land use as well as the reduction in fallow period [27, 25].

Total $\mathrm{N}$ ranged from $0.09-0.10 \%$. It has been indicated that total $\mathrm{N}$ constitutes the bulk of soil organic carbon in the tropics $[28,29,30,25]$. Mean $\mathrm{N}$ value in soils of the various land uses were below critical value of $0.15 \%\left(1.5 \mathrm{gkg}^{-1}\right)$ for soils [2]. Oil palm plantation and fallow land are not significantly different but significantly different from cultivated land; this could be due to the much more rapid mineralization of soil organic matter in cultivated land, leaching and erosion due to the high tropical rainfall [7, 23].

Table-2: Mean values of $\mathrm{pH}$, available $\mathrm{P}$, percentage base saturation (PBS), organic carbon (OC), total nitrogen (TN) and soil organic matter (OM) as influenced by the different land uses

\begin{tabular}{|c|c|c|c|c|c|}
\hline \multirow[t]{2}{*}{ Soil properties } & \multicolumn{3}{|c|}{ Land use types } & \multirow[t]{2}{*}{$L S D(0.05)$} & \multirow[t]{2}{*}{$\overline{C V}(\%)$} \\
\hline & $\begin{array}{l}\text { Oil palm } \\
\text { plantation }\end{array}$ & Cultivated land & Fallow land & & \\
\hline Soil pH $\left(\mathrm{H}_{2} \mathrm{O}\right)$ & $6.25^{a}$ & $5.03^{b}$ & $5.05^{b}$ & 0.31 & 12.8 \\
\hline $\begin{array}{l}\text { Available P } \\
\text { (mg/kg) }\end{array}$ & $10.77^{a}$ & $9.02^{b}$ & $11.45^{\mathrm{a}}$ & 1.49 & 12.0 \\
\hline PBS (\%) & $87.13^{b}$ & $85.22^{c}$ & $90.43^{a}$ & 0.79 & 3.0 \\
\hline OC (\%) & $1.65^{\mathrm{a}}$ & $1.04^{b}$ & $1.96^{\mathrm{a}}$ & 0.44 & 30.2 \\
\hline TN $(\%)$ & $0.09^{a}$ & $0.05^{b}$ & $0.10^{\mathrm{a}}$ & 0.02 & 33.1 \\
\hline OM (\%) & $2.90^{a}$ & $1.79^{b}$ & $3.38^{a}$ & 0.75 & 30.3 \\
\hline
\end{tabular}

Means within column followed by the same letter are not statistically different from each other at $P<0.05$; LSD = least significant difference; $\mathrm{CV}=$ coefficient of variation.

The study on exchangeable bases revealed that all bases did not show similar trends throughout the land use type, the exchangeable $\mathrm{Ca}$ content of fallow land was significantly higher than other land uses.

In general exchangeable $\mathrm{Ca}$ content of different land use types ranges from $4.52-5.83 \mathrm{~mol} / \mathrm{kg}$. According to Jones [8] the exchangeable $\mathrm{Ca}$ content of the study area is rated as medium. The exchangeable $\mathrm{Mg}$ content of different land use types was significant at $(P<0.05)$. Exchangeable $\mathrm{Mg}$ ranged from $2.31-2.56 \mathrm{~mol} / \mathrm{kg}$. Similar to exchangeable $\mathrm{Ca}$, the exchangeable $\mathrm{Mg}$ was high in fallow land and low in cultivated land. The low content of exchangeable $\mathrm{Mg}$ in cultivated fields attributed to soil erosion and abundant crop harvest for the past three decades which contributed to the depletion of $\mathrm{Mg}$ in cultivated lands. The exchangeable Mg 
is medium for cultivated land soil while the exchangeable $\mathrm{Mg}$ contents in fallow and oil palm lands were rated as high [8]. Although exchangeable $\mathrm{Na}$ did not show any significant among the land use types, the Na content was highest in cultivated land; this could be as a result of the application of fertilizers, pesticides and the breakdown of minerals which releases salt. This result corroborate the findings of Yimer et al. [31] who reported that the concentration of soil exchangeable Na was lower in cropland than in the grazing and native forest. The result for exchangeable $K$ indicated that there was significant difference $(P<0.05)$ in all land use types. The lowest $\mathrm{K}$ was observed in cultivated land; this could be as a result of nutrient loss via harvesting.

ECEC was significant in all land use types $(P<0.05)$. Generally, the highest ECEC was observed in fallow land $(12.24$ $\mathrm{mol} / \mathrm{kg}$ ) while the lowest was observed in cultivated lands $(11.04 \mathrm{~mol} / \mathrm{kg})$; the relatively high ECEC recorded in fallow land could be attributed to the fact that fallow land accumulates high percentage $\mathrm{OC}$ and has greater capacity to hold cations, thereby resulting to greater potential facility in the soil which is expected to increase through improvement of the soil OM content.

Exchangeable acidity $(E A)$ was significant in all land use types $(P<0.05)$. Generally, the highest EA was observed in oil palm plantation $(1.46 \mathrm{~mol} / \mathrm{kg})$ while the lowest was observed in cultivated lands $(0.16 \mathrm{~mol} / \mathrm{kg})$; the low EA recorded in all land use types, especially in cultivated land, is in agreement with the findings of Yoshinori et al. [32]. This could be because of the already high level of calcium in the soil which prevented acidification of the cropland.

Table-3: Mean values of exchangeable bases, effective cation exchange capacity (ECEC) and exchangeable acidity (EA) as influenced by the different land uses

\begin{tabular}{|c|c|c|c|c|c|}
\hline \multirow{2}{*}{$\begin{array}{c}\text { Soil } \\
\text { properties } \\
(\mathrm{cmol} / \mathrm{kg})\end{array}$} & \multicolumn{3}{|c|}{ Land use types } & \multirow{2}{*}{$\begin{array}{c}L S D \\
(0.05)\end{array}$} & \multirow{2}{*}{$\begin{array}{l}C V \\
(\%)\end{array}$} \\
\hline & $\begin{array}{l}\text { Oil palm } \\
\text { plantation }\end{array}$ & $\begin{array}{l}\text { Cultivated } \\
\text { land }\end{array}$ & $\begin{array}{l}\text { Fallow } \\
\text { land }\end{array}$ & & \\
\hline $\mathrm{K}$ & $2.09^{c}$ & $1.91^{b}$ & $2.17^{a}$ & 0.07 & 6.5 \\
\hline $\mathrm{Ca}$ & $4.94^{b}$ & $4.73^{b}$ & $5.94^{a}$ & 0.31 & 12.5 \\
\hline Mg & $2.49 b$ & $2.31^{c}$ & $2.60^{a}$ & 0.07 & 6.1 \\
\hline $\mathrm{Na}$ & 0.48 & 0.55 & 0.53 & $0.10 \mathrm{~ns}$ & 6.9 \\
\hline TEB & $10.15^{c}$ & $9.85^{b}$ & $11.16^{a}$ & 0.16 & 6.6 \\
\hline ECEC & $11.61^{b}$ & $11.14^{c}$ & $12.34^{a}$ & 0.10 & 5.2 \\
\hline EA & $1.46^{c}$ & $0.16^{b}$ & $1.18^{\mathrm{a}}$ & 0.07 & 73.6 \\
\hline
\end{tabular}

Means within column followed by the same letter are not statistically different from each other at $\mathrm{P}<0.05$; LSD = least significant difference; $n s=$ not significant; $\mathrm{CV}=$ coefficient of variation.

Correlative relationship between some selected soil properties are presented in table 4. pH correlated positively and not significantly with $\mathrm{K}$ while negatively but significant with silt at $\mathrm{P}<0.05$ and sand and clay at $\mathrm{P}<0.01$. The strong correlation of total $\mathrm{N}$ with organic carbon suggests that most $\mathrm{N}$ is stored in soil organic matter. Calcium correlates negatively but significantly with exchangeable acidity which suggests that exchangeable acidity decreases with increasing level of calcium in soil. Percent base saturation correlates negatively but significantly with exchangeable acidity which suggest that percent base saturation increases with decreasing exchangeable acidity.

Table-4: Correlation matrix of some soil properties

\begin{tabular}{|c|c|c|c|c|c|c|c|c|c|c|c|c|c|c|c|}
\hline & $\mathrm{pH}$ & AP & $\mathrm{K}$ & $\mathrm{Ca}$ & $\mathrm{Mg}$ & $\mathrm{Na}$ & TEB & ECEC & \%BS & $\% O C$ & $\% \mathrm{OM}$ & $\% \mathrm{TN}$ & Sand & Silt & Clay \\
\hline $\mathrm{AP}$ & .266 & & & & & & & & & & & & & & \\
\hline $\mathrm{K}$ & .089 & $.883^{* *}$ & & & & & & & & & & & & & \\
\hline $\mathrm{Ca}$ & -.437 & .627 & $.823^{* *}$ & & & & & & & & & & & & \\
\hline $\mathrm{Mg}$ & .054 & $.873^{* *}$ & $.986^{\star *}$ & $.868^{* *}$ & & & & & & & & & & & \\
\hline $\mathrm{Na}$ &,- 336 & -.130 & -.206 & -.034 & -.203 & & & & & & & & & & \\
\hline TEB & -.220 & $.793^{*}$ & $.936^{* *}$ & $.966^{* *}$ & $.959^{* *}$ & -.111 & & & & & & & & & \\
\hline ECEC & -.201 & $.804^{* *}$ & $.925^{\star *}$ & $.962^{* *}$ & $958^{* *}$ & -.119 & $997^{* *}$ & & & & & & & & \\
\hline \%BS & -.297 & $.714^{*}$ & $.920^{* *}$ & $.970^{* *}$ & $930^{* *}$ & $\begin{array}{l}.091 \\
\end{array}$ & $985^{\star *}$ & $.969^{* *}$ & & & & & & & \\
\hline$\% O C$ & .346 & $.913^{* *}$ & $.677^{*}$ & .477 & $.716^{*}$ & $\begin{array}{l}.124 \\
\end{array}$ & .629 & .672 & .497 & & & & & & \\
\hline$\% O M$ & .371 & $.916^{\star *}$ & $.681^{*}$ & .466 & $.717^{*}$ & $\begin{array}{l}-137 \\
\end{array}$ & .624 & .666 & .491 & $998^{* *}$ & & & & & \\
\hline$\% \mathrm{TN}$ & .459 & $.897^{\star *}$ & $.672^{*}$ & .424 & $.711^{*}$ & -.190 & .591 & .635 & .457 & $.989^{\star *}$ & $.993^{\star *}$ & & & & \\
\hline Sand & $.890^{* *}$ & .347 & .308 & -.125 & .319 & -.422 & .048 & .066 & -.012 & .397 & .420 & .520 & & & \\
\hline Silt & $-.692^{*}$ & -.102 & .179 & .365 & .094 & .194 & .274 & .009 & .408 & -.432 & -.441 & -.511 & -629 & & \\
\hline Clay & $-.866^{* *}$ & -.368 & -.375 & .074 & -.372 & .438 & -.103 & -.111 & -.060 & -.365 & -.389 & -.487 & $-.991^{* *}$ & .576 & \\
\hline EA & .274 & $-.734^{*}$ & $-.932^{\star *}$ & $-.950^{* *}$ & $-.930^{* *}$ & .088 & $-.979^{* *}$ & $-.958^{\star *}$ & $-.997^{* *}$ & -.497 & -.492 & -.456 & .012 & -.438 & .065 \\
\hline
\end{tabular}

${ }^{* *}$ correlation is significant at $P<0.01$ level *correlation is significant at $P<0.05$ level. 


\section{CONCLUSION}

The study reveals that there was a decline in most of the parameters measured in the cultivated land as compared to oil palm plantation and fallow land. This could be due to mechanical impact on the soil, nutrient uptake by plants, run-off, erosion, bush burning, crops removal, chemical fertilizer application and climate change on cultivated land. Cultivated land had low total N, OC, available $P, E C E C$ and exchangeable bases. The result of the findings also reveals that fallow land had the highest content of $O C$ TN, available P and ECEC; this is obvious because of litter accumulation on the surface of the soil over time which favours nutrient recycling. It is pertinent to encourage farmers to periodically fallow their lands or leave litters on the soil to sequester organic matter, stabilize soil aggregates, combat land degradation and improves nutrient cycling for sustainable agricultural production.

\section{REFERENCES}

1. Wilson, B. R., Growns, I., \& Lemon, J. (2008). Land-use effects on soil properties on the north-western slopes of New South Wales: Implications for soil condition assessment. Soil Research, 46(4), 359-367.

2. Senjobi, B.A., \& Ogunkunle, A.O. (2011). Effect of different land use types and their implications on land degradation and productivity in Ogun State, Nigeria Journal of Agricultural Biotechnology and Sustainable Development, 3(1), 7-18.

3. Ahukaemere, C. M, Ndukwu, B. N \& Agim, L. C. (2012). Soil Quality and Soil Degradation as Influenced by Agricultural Land use Types in the Humid Environment. International Journal of Forest, Soil and Erosion, 2 (4), 23 -28.

4. Geist, H. J. \& Lambin, E. F. (2002). Proximate causes and underlying driving forces of tropical deforestation. Bioscience, 52(2), $143-150$.

5. Heiman, M. \& Reichstein, M. (2008). Terrestial ecosystem carbon dynamics and climate feedback. Nature, 45(17), 289 - 291.

6. FAO. (1984). Guidelines for land use planning. FAO development series. FAO Rome, 96.

7. FAO. (1997). State of the world's forests Food and Agriculture Organization, Rome, Italy, 200.

8. Senjobi, B. A. (2007). Comparative Assessment of the Effect of Land Use and Land Type on Soil Degradation and Productivity in Ogun State, Nigeria. 161pp. Unpublished Ph. D. Thesis submitted to the Department of Agronomy, University of Ibadan, Nigeria.

9. Jones, J.B. (2003). Agronomic Handbook: management of crops, soils, and their fertility. CRC Press, Boca Raton, Florida, USA.

10. Amhakhian, S.O., \& Osemwota, I.O. (2010). Physical and chemical properties of soils in Kogi State, Guinea savanna of Nigeria. Nigerian journal of soil science. 22, 46-54.

11. Gee, G. W. \& Or, D. (2002). Particle size analysis in: Dane, J. H., Topp, G. C., (eds.). Methods of Soil analysis part 4, physical methods. soil science society. Am book series, No 5 ASA and SSSA Madison 1, 255 -295.

12. Walkley, A., \& Black, C. A. (1934). An examination of Digestion method for determining soil organic matter and proposed modification of the proposed modification of the chromic acid titration method. Soil Science, 37, 29-38.

13. Bremner, J. M. (1996). Nitrogen total. Sparks, D. L. (eds.) methods of soils analysis, parts, chemical mth. 2nd ed, SSSA book series No 5, SSSA, Madison, WI, $1085-1125$.

14. Brady, N. C., \& Weil, R. R. (2002). The nature and properties of soils (13th eds.). The lowa State, India: PVT. Ltd.

15. Rayment, G. E., \& Lyons, D. J. (2011). Soil chemical methods: Australasia (Vol. 3). CSIRO publishing.

16. Hendershot, W. H., Lalande, H., \& Duquette, M. (1993). Soil sampling and methods of analysis. Canadian Society of Soil Science. Lewis Publishers, London.

17. Sparks, D. L., Page, A. L., Helmke, P. A., Loeppert, R. H., Soltanpour, P. N., Tabatabai, M. A., ... \& Sumner, M. E. (1996). Methods of soil analysis, part 3. Chemical methods, 1085-1121.

18. Mclean, E. V. (1982). Aluminium. In page, A. L., Miller, R. H., Keeney, D. R., (eds). Methods of soil analysis, part 2, Am. Soc. Agron Madison WL. 978 - 998.

19. Mengel, D. (2001). Development of Agronomy, Purdue University. "fundamentals of soil cation exchange capacity". retrieve 2011 05-03, from http://www.agric.gov.ab.ca/flippingbook/agdex/400_28-3/

20. Obi, V.I. (1999). Natural pesticide production for sustainable agricultural production in Nigeria: a vision for the $21^{\text {st }}$ century. Nigeria journal of educational innovation, 1(2), $44-50$.

21. Olson, S.R. \& Sommers, L.E. (1990). Phosphorus. In: Methods of Soil Analysis. Parts 2, Ed., Page, A.L. Agron., Monogr. No. 9 Madison, WI, 403-431.

22. Ndukwu, B.N., Idigbor, C.M., Onwudike, S.U., Okafor, P.O. \& Osuaku, S.K. (2009). Spatial Variability in some Properties of Soils formed under different Lithologies in Southeastern Nigeria. In the Proceeding of the 5 th National Conference of Organic Agriculture Project in Tertiary Institution in Nigeria, 94-97.

23. Bezabih, B., Aticho, A., Mossisa, T., \& Dume, B. (2016). The effect of land management practices on soil physical and chemical properties in Gojeb Sub-river Basin of Dedo District, Southwest Ethiopia. Journal of Soil Science and Environmental Management, $7(10), 154-165$

24. Uzoho, B.U., Oti, N.N. \& Ngwuta, A.A. (2007). Fertility status under land use types of soil similar lithology. Journal of American Society, 3(4), 20-29

25. Onweremadu, E. U., Akamigbo, F. O. R. \& Igwe, C. A. (2008). Soil quality morphological index in relation to organic carbon content of soils in south-eastern Nigeria. Trends in Applied Science research 3(1), 76-82.

26. Anikwe, M. A. (2010). Carbon storage in soils of Southeastern Nigeria under different management practices. Carbon balance and management, 5(1), 5. 
27. Enwezor, W.O., Ohiri, A.C., Opuwaribo, E.E. \& Udo, E.J. (1990). Literature Review on Soil Fertility Investigation in Nigeria. Federal Ministry of Natural Resources Lagos.

28. Akinrinde, E. A., \& Obigbesan, G. O. (2000, October). Evaluation of the fertility status of selected soils for crop production in five ecological zones of Nigeria. In Proceedings of the 26th Annual Conference of Soil Science Society of Nigeria, Ibadan, Nigeria: 279-288.

29. Akamigbo, F. O. R. (1999). Influence of land use on the soil properties of the humid agroecology of southeastern Nigeria. Nigeria Agricultural Journal, 30, 59-76

30. Igwe, C.A., Akamigbo, F.O.R. \& Mbagwu, J.S.C. (1999). Chemical and mineralogical properties of soils in south eastern Nigeria in relation to aggregate stability. Geoderma, 92(1-2): 111-123.

31. Noma, S.S., Ojanuga, A.G., Ibrahim, S.A. \& Iliya, M.A. (2005). Detailed soil survey of Sokoto - Rima floodplain at Sokoto. In managing oil resources for food security and sustainable environment Proc. 29 Annual Conference of Soil Science Society of Nigeria.

32. Yimer, F., Messing, I., Ledin, S. \& Abdelkadir, A. (2008). Effects of different land use types on infiltration capacity in a catchment in the highlands of Ethiopia. Soil Use Management, 24(4), 56-62.

33. Yoshinori, W., Hidehiko, K., Robert, A., Tsugiyuki, M. \& Toshiyuki, W. (2015). Comparison of Physicochemical Properties of Soils under Contrasting Land Use Systems in South-western Nigeria. Japan Agricultural Research Quarterly, 49(4), 319-331. 